\title{
Parasitoids diversity in organic Sweet Pepper (Capsicum annuum) associated with Basil (Ocimum basilicum) and Marigold (Tagetes erecta)
}

\author{
I. L. Souza ${ }^{a *}$, V. B. Tomazella ${ }^{a}$, A. J. N. Santos ${ }^{b}$, T. Moraes ${ }^{c}$ and L. C. P. Silveira \\ ${ }^{a}$ Laboratório de Controle Biológico Conservativo, Departamento de Entomologia, Universidade Federal de Lavras - \\ UFLA, Av. Doutor Sylvio Menicucci, 1001, Kennedy, CEP 37200-000, Lavras, MG, Brasil \\ ${ }^{\mathrm{b}}$ Companhia Nacional de Abastecimento - CONAB, Rua Tobias Barreto, s/n, Bebedouro, CEP 57013-000, Maceió, AL, \\ Brasil \\ 'Laboratório de Ecologia Molecular de Artrópodes, Departamento de Entomologia, Escola Superior de Agricultura \\ "Luiz de Queiroz" - ESALQ, Av. Pádua Dias, 11, CEP 13418-900, Piracicaba, SP, Brasil \\ *e-mail: ilemossouza@gmail.com
}

Received: September 17, 2017 - Accepted: March 26, 2018 - Distributed: November 30, 2019

(With 5 figures)

\begin{abstract}
The sweet pepper (Capsicum annuum L.) is one of the most important crops in Brazilian farming. Many insect are related to this crop, compromising the quantity and quality of the fruit, representing a production problem. Vegetable diversification is one of the main elements that can be managed for suppressing undesirable insect populations in organic production, once that supports the presence of natural enemies. The basil Ocimum basilicum L. and the marigold Tagetes erecta L. are attractive and nutritious plants for parasitoids, being important candidates for diversified crops. This study evaluated the parasitoids attracted by the association of basil and marigold to organic sweet pepper crop. The experiment comprised three treatments: a) sweet pepper monoculture; b) sweet pepper and basil intercropping; c) sweet pepper and marigold intercropping. Hymenopteran parasitoids were collected over 14 weeks. 268 individuals from 12 families and 41 taxa were collected. Sweet pepper monoculture, sweet pepper-basil intercropping, and sweet pepper-marigold intercropping hosted 40, 98, and 130 individuals and richness of 24, 24, and 23, respectively. Furthermore, the insects of greater abundance in the basil and marigold were different to those collected in the monoculture. The number of parasitoids increased in the associations of sweet pepper with basil and marigold, providing advantages in the use of vegetable diversification for the organic pepper crops management.
\end{abstract}

Keywords: conservation biological control, natural enemies, vegetable diversification.

\section{Diversidade de parasitoides em Pimentão Orgânico (Capsicum annuum) associado com Manjericão (Ocimum basilicum) e Cravo Amarelo (Tagetes erecta)}

\section{Resumo}

O pimentão (Capsicum annuum L.) é um dos vegetais mais importantes dentre os cultivados no Brasil. Muitos insetos pragas estão relacionados a esta cultura, comprometendo a quantidade e a qualidade do pimentão, tornando-se um grande problema para a produção. A diversificação vegetal é um dos principais componentes a serem manejados para suprimir as populações de pragas na produção orgânica, devido ao apoio a inimigos naturais das pragas. O manjericão (Ocimum basilicum L.) e cravo amarelo (Tagetes erecta L.) são plantas atrativas e nutritivas para parasitoides, importantes candidatas em cultivos diversificados. Este trabalho avaliou os parasitoides atraídos pela associação de manjericão e cravo amarelo em cultivo de pimentão orgânico. O experimento foi composto por três tratamentos: a) monocultura de pimentão; B) pimentão consorciado com manjericão; C) pimentão consorciado com cravo amarelo. Foram coletadas amostras de parasitoides himenópteros durante 14 semanas. Os espécimes foram identificados até o menor nível de taxonomia possível. Foram coletados 268 indivíduos ao longo de 12 famílias e 41 táxons. Os tratamentos de monocultura, pimentão consorciado com manjericão e pimentão consorciado com cravo amarelo resultaram em 40, 98 e 130 indivíduos e riqueza de espécies de 24, 24 e 23, respectivamente. Além disso, os insetos de maior abundância coletados no manjericão e cravo amarelo, foram diferentes daqueles coletados na monocultura. Houve um aumento na abundância de parasitoides nas associações de pimentão com manjericão e cravo amarelo, proporcionando vantagens no uso da diversificação vegetal, podendo ser usada no manejo do pimentão orgânico.

Palavras-chave: controle biológico conservativo, inimigos naturais, diversificação vegetal. 


\section{Introduction}

Sweet pepper (Capsicum annuum L., 1753) is one of the most significant greenery cultivated in Brazil, with an annual production close to 290,000 tons of fruits. It is cultivated nationwide, especially in the states of São Paulo, Minas Gerais, Bahia, and Rio de Janeiro, which are the main producers (Marouelli and Silva, 2012).

Many arthropods are associated to this culture, and the damage from pests compromises the quantity and quality of the fruit, becoming a great problem to the production. The principal control method used is the application of phytosanitary products. In the ranking for foods with the highest pesticides index, sweet pepper is the leader. Almost all the cultivations in Brazil show high irregularities, as the presence of non-authorized active ingredients, and in higher concentrations than the maximum authorized by law (ANVISA, 2013).

The result of this inadequate management is the loss of ecological functions such as pollination and biological control, reducing the population of beneficial insects (Kruess and Tscharntke, 1994; Tilman et al., 2002; Poveda et al., 2008). Furthermore, it induces pesticide resistance in insects (Martins et al., 2012), hindering its control and increasing production cost.

On the other hand, the organic farming production adopts sustainable techniques, mainly aiming at improving the plant quality, and is an answer to the conventional production model, acting efficiently in maintaining the production of healthy plants without using phytosanitary products (Azadi et al., 2011).

Vegetable diversification is one of the main elements that can be managed to suppress undesirable insect populations in organic productions, for example, through the association of vegetable species. The simplification observed in conventional cultivation, generally characterized by monocultures, is considered responsible in part for the high incidence of pests and diseases (Michele, 1996). The inclusion of suitable vegetable species, in addition to diversified crops, guarantees the diversification and conservation of natural enemies.

The basil Ocimum basilicum L. (Lamiales: Lamiaceae) is an aromatic plant, cultivated in many countries due to its economic importance and great adaptability (Carović-Stanko et al., 2010). The Ocimum genus has aromatic compounds as methyl eugenol, linalool, and, specially, eugenol, which are the most important constituents of the basil essential oil (Bhuvaneshwari et al. 2016). These compounds have nematicidal, pro-oxidants, anti-oxidants, dental anesthetics and disinfectant activity, as well as protect agents against nicotine toxicity in murine peritoneal macrophages (Kaya et al., 2008; Anamika et al., 2013).

The marigold Tagetes erecta L. (Asterales: Asteraceae) is a plant widely used in crop diversification studies on agricultural crops. Its colorful flowers, presence of nectar, and pollen can harbor alternative prey; moreover, it contains secondary metabolites that perform biological functions in nature, being able to control pests and diseases (Salinas-Sánchez et al., 2012). Marigold leaves and flowers have a volatile oil composed by a mixture of 29 and 27 compounds respectively (Haro, 2014). Among them, it stands out the (E)- $\beta$-farnesene found in leaves and flowers, compounds used by aphids as an alarm pheromone against predators (Bowers et al., 1972). Marigold plants also presents potential to diminish the use of synthetic insecticides (Serrato et al., 2007)

Flowering plants are used to maximize the biological pest control in agroecosystems, depending on the natural enemies' acceptance. Adult parasitoids have a free life, their nutritional needs are based on amino acids, vitamins, minerals, carbohydrates, lipids, and sterols (Panizzi and Parra, 2009), which promote higher longevity, search efficiency, and reproductive capacity (Mitsunaga et al. 2004, 2006), and may be available on pollen and nectar from the flowers.

The aromatic plants may be effective candidates to constitute diversified plantations since they can be cultivated in partially shaded environment, and are attractive and nutritious to predators and parasitoids due to their oils' fragrance and the nutrients they contain (Song et al. 2010).

Basedow et al. (2006) found that the association of basil with broad bean (Vicia faba L.) (Fabales: Fabaceae) act as repellent to the black bean aphid (Aphis fabae Scopoli) (Hemiptera: Aphididae), bringing benefits to the main crop. Roxas (2009) found that the association of chinese cabbage (Brassica pekinensis (Lour.) Rupr.) (Brassicales: Brassicaceae) with basil reduced the population of striped flea beetle (Phyllotreta striolata Fabricius) (Coleoptera: Chrysomelidae). In a study conducted by Montserrat et al. (2012), it has been shown that the use of basil facilitates the installation of Orius laevigatus Fieber (Hemiptera: Anthocoridae), predator of thrips, aphids, white-flies, and mites in sweet pepper plantation. There are few studies on the diversification between vegetables and basil, and even less information on the effects of its parasitoids to the detriment of insect pests.

Studies conducted on the $T$. erecta association to different crops shown that its presence aid in natural pest regulation and act in the attraction of their natural enemies. According to Silveira et al. (2009), lines of marigold close to onion crops promote higher richness and abundance of parasitoids when compared with lines containing only onion. Nevertheless, our goal was to evaluate the attraction of parasitoids by the association of basil and marigold in organic sweet pepper plantation, as follows: 1) increases in abundance, richness, and diversity of parasitoids associated to the basil; 2) increases in abundance, richness, and diversity of parasitoids associated to marigold. 


\section{Material and Methods}

The experiment was conducted in an organic field at the Olericulture sector $\left(21^{\circ} 13\right.$ '51.06”' S, 4458'34.36" W, $905 \mathrm{~m}$ of altitude), in the Agriculture department of the Federal University of Lavras, in Lavras, MG. The experiment was composed of three treatments: a) in the sweet pepper monoculture: 72 plants were used, distributed in 4 garden beds with $60 \mathrm{~cm}$ between the plants and $1 \mathrm{~m}$ between the lines, with 9 plants in each line and 18 plants per bed; b) for the association of sweet pepper and basil: 72 sweet peppers plants were used with same spacing as the other treatment, and the basil were planted at the borders in a spacing of $40 \mathrm{~cm}$, being 72 plants in total; c) for the association of sweet pepper and marigold: 72 sweet peppers plants were used with same spacing, and marigold was planted at the borders in a spacing of $40 \mathrm{~cm}$, containing 72 plants in total.

The Hymenoptera parasitoids samples were collected weekly. The sampling process started five weeks after the sweet pepper seedlings transplantation, fifteen days after the transplantation of basil and marigold, and was conducted over 14 weeks.

Two pan traps adapted from Moericke (1951) were fixed $15 \mathrm{~cm}$ below the average height of the sweet pepper plants in each treatment. These traps were developed for the sampling of flying insects in different altitudes in crop plantations or natural ecosystems, giving good results (Moericke, 1951), being useful in this case to verify the parasitoids flux along treatments. All parasitoids were counted and brought to Conservation Biological Control Laboratory on the Entomology Department of UFLA for identification. The specimen were identified to the lowest taxonomy level possible using the identification keys of
Fernández and Sharkey (2006) and through consultation with specialists (Taxonomists).

The diversity index: a) Insect richness, which is used to evaluate the composition of insect species in a community; b) Diversity, using Shannon H', an index to evaluate the diversity of the community; c) Insect abundance, which shows total number of insects collected; and d) Dominance, using the Berger-Parker test, which shows if there is a specie more dominant than the others; were all estimated through the Software Past ${ }^{\circledR}$, and their mean was analysed by the Scott Knott test at a level of significance of 5\%, using the R Studio Package ExpDes.pt. To evaluate the community composition a Non-Metric Multidimensional Scaling (NMDS) was performed, using Bray-Curtis as a similarity index. After, the data was submitted to an analyse of similarity (ANOSIM) to find the numeric differences in the composition and, following, SIMPER tests were used to see which insects were responsible for the difference. All those tests were conducted with PAST ${ }^{\circledR}$ software (Hammer et al., 2001), and mean differences were performed at R Studio Software (R Development Core Team, 2015).

\section{Results}

Two hundred and sixty-eight individuals, from 12 families and 41 taxa were collected. Each treatment: monoculture, sweet pepper-basil intercropping, and sweet pepper-marigold intercropping, hosted 40, 98, and 130 insects, respectively (Table 1 ). The plants of basil and marigold affected the increase in the parasitoid abundance index $(\mathrm{CV}=36.19 \%$, d.f. $=11, P=0.010208)$ when compared to the plantation with only sweet pepper (Figure 1).

Table 1. Parasitoids taxon abundance and frequency in monoculture sweet pepper (MBP), associated with basil (BPB), marigold (BPMg), and richness.

\begin{tabular}{|c|c|c|c|c|c|c|}
\hline \multirow{2}{*}{ Families and Species } & \multicolumn{2}{|c|}{ MBP } & \multicolumn{2}{|c|}{ BPB } & \multicolumn{2}{|c|}{ BPMg } \\
\hline & $\mathbf{n}$ & freq. & $\mathbf{n}$ & freq. & $\mathbf{n}$ & freq. \\
\hline \multicolumn{7}{|l|}{ Bethylidae } \\
\hline Dissomphalus sp.1 Ashmead. 1893 & - & - & 2 & 2.04 & 1 & 0.77 \\
\hline \multicolumn{7}{|l|}{ Braconidae } \\
\hline Aleiodes sp.1 Wesmael. 1838 & - & - & - & - & 1 & 0.77 \\
\hline Apanteles sp.1 Förster. 1862 & 1 & 2.5 & 7 & 7.14 & 32 & 24.62 \\
\hline Aphidius platensis Viereck. 1912 & - & - & 1 & 1.02 & 2 & 1.54 \\
\hline Aphidius ervi Haliday. 1834 & - & - & 1 & 1.02 & - & - \\
\hline Aphidius sp.1 Nees. 1818 & - & - & 1 & 1.02 & 4 & 3.08 \\
\hline Cotesia sp.1 Cameron. 1891 & 1 & 2.5 & 1 & 1.02 & - & - \\
\hline Deuterixys sp.1 Mason. 1981 & - & - & - & - & 1 & 0.77 \\
\hline Distatrix sp.1 Mason. 1981 & - & - & - & - & 2 & 1.54 \\
\hline Glyptapanteles sp.1 Ashmead. 1904 & 1 & 2.5 & 1 & 1.02 & - & - \\
\hline Hypomicrogaster sp.1 Ashmead. 1898 & - & - & - & - & 1 & 0.77 \\
\hline Meteorus sp.1 Haliday. 1835 & 2 & 5 & 2 & 2.04 & 8 & 6.15 \\
\hline Microgastrinae sp.1 Förster. 1862 & - & - & - & - & 2 & 1.54 \\
\hline Opius sp.1 Wesmael. 1835 & 2 & 5 & - & - & 2 & 1.54 \\
\hline \multicolumn{7}{|l|}{ Diapriidae } \\
\hline Coptera sp.1 Say. 1816 & - & - & 2 & 2.04 & - & - \\
\hline
\end{tabular}


Table 1. Continued...

\begin{tabular}{|c|c|c|c|c|c|c|}
\hline \multirow{2}{*}{ Families and Species } & \multicolumn{2}{|c|}{ MBP } & \multicolumn{2}{|c|}{ BPB } & \multicolumn{2}{|c|}{ BPMg } \\
\hline & $\mathbf{n}$ & freq. & $\mathbf{n}$ & freq. & $\mathbf{n}$ & freq. \\
\hline \multicolumn{7}{|l|}{ Dryinidae } \\
\hline \multicolumn{7}{|l|}{ Table 1 continued... } \\
\hline Aphelopinae sp.1 Perkins. 1912 & - & - & - & - & 1 & 0.77 \\
\hline \multicolumn{7}{|l|}{ Encyrtidae } \\
\hline Copidosoma sp.1 Ratzeburg. 1844 & - & - & 1 & 1.02 & 4 & 3.08 \\
\hline Metaphycus sp.1 Mercet. 1917 & 1 & 2.5 & 1 & 1.02 & 1 & 0.77 \\
\hline \multicolumn{7}{|l|}{ Eulophidae } \\
\hline Aprostocetus sp.1 Westwood. 1833 & - & - & - & - & 1 & 0.77 \\
\hline Chrysocharis sp.1 Förster. 1856 & 1 & 2.5 & - & - & - & - \\
\hline Entedonastichus sp.1 Girault. 1920 & 1 & 2.5 & - & - & - & - \\
\hline Euderomphale sp.1 Girault. 1916 & 1 & 2.5 & 1 & 1.02 & - & - \\
\hline Thripastichus sp.1 Graham. 1987 & 1 & 2.5 & - & - & - & - \\
\hline \multicolumn{7}{|l|}{ Figitidae } \\
\hline Aganaspis sp.1 Lin. 1987 & 3 & 7.5 & 1 & 1.02 & 6 & 4.62 \\
\hline Didyctium sp.1 Riley. 1879 & 3 & 7.5 & 40 & 40.82 & 34 & 26.15 \\
\hline Gronotoma sp.1 Förster. 1869 & 1 & 2.5 & 1 & 1.02 & - & - \\
\hline \multicolumn{7}{|l|}{ Ichneumonidae } \\
\hline Anomalon cuetoi Gauld \& Bradshaw. 1997 & 1 & 2.5 & 1 & 1.02 & 3 & 2.31 \\
\hline Anomalon sinuatum Morlers. 1912 & 1 & 2.5 & 4 & 4.08 & - & - \\
\hline Campopleginae Förster sp.1 1869 & 1 & 2.5 & 0 & 0.00 & 1 & 0.77 \\
\hline Campopleginae Förster sp.2 1869 & 1 & 2.5 & 1 & 1.02 & - & - \\
\hline Campopleginae Förster sp.3 1869 & - & - & - & 0.00 & 2 & 1.54 \\
\hline Cryptinae sp. 1 Kirby. 1837 & - & - & 1 & 1.02 & - & - \\
\hline Ichneumoninae sp.1 Latreille. 1802 & 1 & 2.5 & - & - & - & - \\
\hline Table 1 continued... & & & & & & \\
\hline Syzeuctus sp.1 Foerster. 1869 & 1 & 2.5 & - & - & - & - \\
\hline \multicolumn{7}{|l|}{ Megaspilidae } \\
\hline Dendrocerus sp.1 Chow. 2000 & 2 & 5 & - & - & - & - \\
\hline \multicolumn{7}{|l|}{ Mymaridae } \\
\hline Cleruchus sp.1 Enock. 1909 & - & - & - & - & 1 & 0.77 \\
\hline Polynema sp.1 Haliday. 1833 & 7 & 17.5 & 20 & 20.41 & 16 & 12.31 \\
\hline \multicolumn{7}{|l|}{ Platygastridae } \\
\hline Inostemma sp.1 Haliday. 1833 & - & - & 1 & 1.02 & - & - \\
\hline \multicolumn{7}{|l|}{ Pteromalidae } \\
\hline Halticoptera sp.1 Spinola. 1911 & 2 & 5 & 1 & 1.02 & - & - \\
\hline Pachyneuron sp.1 Walker. 1833 & 1 & 2.5 & 1 & 1.02 & - & - \\
\hline Telenomus sp.1 Haliday. 1833 & 3 & 7.5 & 5 & 5.10 & 4 & 3.08 \\
\hline Total & 40 & 100 & 98 & 100 & 130 & 100 \\
\hline Richness & \multicolumn{2}{|c|}{24} & \multicolumn{2}{|c|}{24} & \multicolumn{2}{|c|}{23} \\
\hline
\end{tabular}

Overall, Richness showed 24 basil's and 23 marigold's treatments, not different from the 24 sweet pepper treatments $(\mathrm{CV}=32.39 \%$, d.f. $=11, P=0.69109)$ (Table 1) (Figure 2). The species similarity was different between the monoculture treatment and both diversification treatments, ( $p=0.0287)$ basil and $(p=0.0301)$ marigold, by ANOSIM test (Table 2). The diversification treatments of basil (1.73) and marigold (1.78) did not present Shannon diversity index $(\mathrm{CV}=16.34 \%$, d.f. $=11, P=0.22702)$, differently from the monoculture (2.1) (Figure 3). There was a dominance (Figure 4) of Berger-Parker index among the treatments, with sweet pepper 0.20 , basil 0.41 , and marigold 0.45 ,

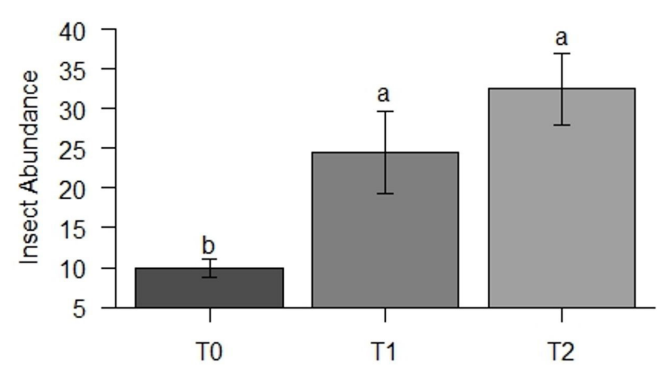

Figure 1. Graphic of Insect abundance with standard errors and significance letters of treatments. T0 - Sweet Pepper Monoculture, T1 - Sweet Pepper associated with Basil and T2- Sweet Pepper associated with Marigold. 
showing a significant difference between monoculture and diversified plantation $(\mathrm{CV}=24.93 \%$, d.f. $=11, P=0.00804)$.

The monoculture treatment was different from the associated treatments with basil and marigold, and had distinct grouping; the low stress value $(0.1623)$ indicated the reliability of such treatments (Figure 5). There was a $75.12 \%$ dissimilarity between monoculture treatment and associated treatment with basil (Table 3), and 79.75\% dissimilarity with treatment associated with marigold

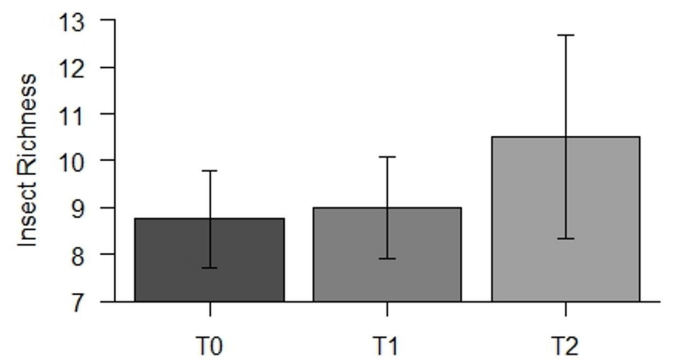

Figure 2. Graphic of Insect Richness with standard errors of treatments. T0 - Sweet Pepper Monoculture, T1 - Sweet Pepper associated with Basil and T2 - Sweet Pepper associated with Marigold.

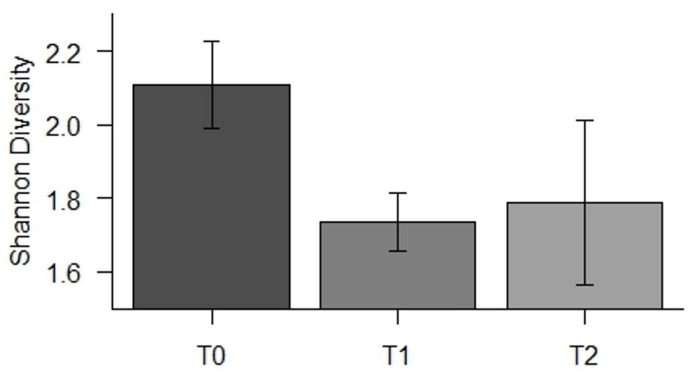

Figure 3. Graphic of Shannon diversity index with standard errors of treatments. T0 - Sweet Pepper Monoculture, T1 - Sweet Pepper associated with Basil and T2 - Sweet Pepper associated with Marigold.
(Table 4). Furthermore, there was $56.45 \%$ dissimilarity between the two associated treatments (Table 5) on the SIMPER test.

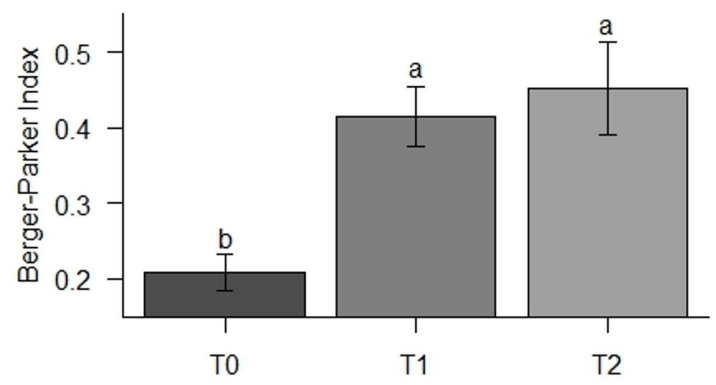

Figure 4. Graphic of Berger-Parker index with standard errors and significance letters of treatments. T0 - Sweet Pepper Monoculture, T1 - Sweet Pepper associated with Basil and T2- Sweet Pepper associated with Marigold.

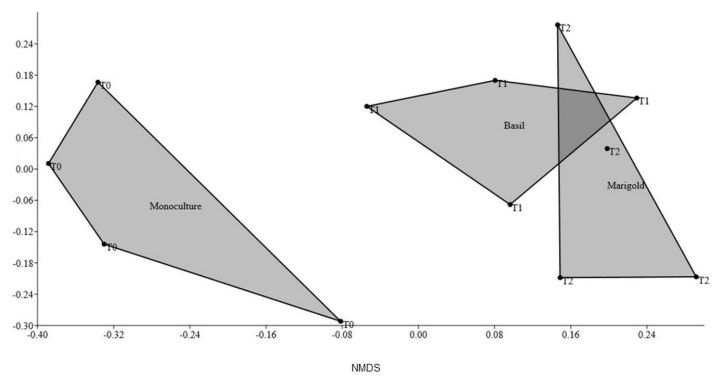

Figure 5. Graphic of NMDS of treatments stress $=0,1615$.

Table 2. ANOSIM of treatments, RGlobal $=0.4283, \mathrm{p}<0.05$ and 9999 permutations.

\begin{tabular}{lccc}
\hline & Monoculture & Basil & Marigold \\
\hline Monoculture & 0 & 0.0287 & 0.0301 \\
Basil & 0.0287 & 0 & 0.49 \\
Monoculture & 0.0301 & 0.49 & 0 \\
\hline
\end{tabular}

Table 3. SIMPER test between monoculture and basil treatments, showing the insects that contributed with $70 \%$ of the difference between treatments.

\begin{tabular}{|c|c|c|c|c|c|}
\hline & \multicolumn{2}{|c|}{ Average dissimilarity $=75.12$} & \multirow{2}{*}{ Basil } & \multirow{3}{*}{ Contribution \% } & \multirow{3}{*}{ Cumulative \% } \\
\hline & \multirow{2}{*}{ Species } & Monoculture & & & \\
\hline & & Mean Abundance & Mean Abundance & & \\
\hline 1. & Didyctium sp. 1 & 0.75 & 10 & 33.05 & 33.05 \\
\hline 2. & Polynema sp. 1 & 1.75 & 5 & 12.34 & 45.39 \\
\hline 3. & Apanteles sp. 1 & 0.25 & 1.75 & 6.826 & 52.21 \\
\hline 4. & Telenomus sp. 1 & 0.75 & 1.25 & 5.077 & 57.29 \\
\hline 5. & Anomalon sinuatum & 0.25 & 1 & 3.505 & 60.8 \\
\hline 6. & Meteorus sp. 1 & 0.5 & 0.5 & 2.964 & 63.76 \\
\hline 7. & Aganaspis sp. 1 & 0.75 & 0.25 & 2.694 & 66.45 \\
\hline 8. & Dissomphalus sp. 1 & 0 & 0.5 & 2.283 & 68.74 \\
\hline 9. & Halticoptera sp. 1 & 0.5 & 0.25 & 2.204 & 70.94 \\
\hline
\end{tabular}


Table 4. SIMPER test between monoculture and marigold treatments, showing the insects that contributed with $70 \%$ of the difference between treatments.

\begin{tabular}{|c|c|c|c|c|}
\hline \multicolumn{2}{|c|}{ Average dissimilarity $=\mathbf{7 9 . 7 5}$} & \multirow{2}{*}{ Marigold } & \multirow{3}{*}{ Contribution \% } & \multirow{3}{*}{ Cumulative \% } \\
\hline \multirow{2}{*}{ Species } & Monoculture & & & \\
\hline & Mean Abundance & Mean Abundance & & \\
\hline 1. Didyctium $\mathrm{sp} .1$ & 0.75 & 8.5 & 25.65 & 25.65 \\
\hline 2. Apanteles sp. 1 & 0.25 & 8 & 21.25 & 46.9 \\
\hline 3. Polynema sp. 1 & 1.75 & 4 & 6.815 & 53.71 \\
\hline 4. Meteorus sp. 1 & 0.5 & 2 & 5.095 & 58.81 \\
\hline 5. Telenomus sp. 1 & 0.75 & 1 & 3.544 & 62.35 \\
\hline 6. Aganaspis sp. 1 & 0.75 & 1.5 & 3.461 & 65.81 \\
\hline 7. Aphidius sp. 1 & 0 & 1 & 2.918 & 68.73 \\
\hline 8. Copidosoma $\mathrm{sp} .1$ & 0 & 1 & 2.467 & 71.2 \\
\hline
\end{tabular}

Table 5. SIMPER test between Basil and Marigold treatments, showing the insects that contributed with $70 \%$ of the difference between treatments.

\begin{tabular}{|c|c|c|c|c|}
\hline \multicolumn{2}{|c|}{ Average dissimilarity $=56.45$} & \multirow{2}{*}{ Marigold } & \multirow{3}{*}{ Contribution \% } & \multirow{3}{*}{ Cumulative \% } \\
\hline \multirow{2}{*}{ Species } & Basil & & & \\
\hline & Mean Abundance & Mean Abundance & & \\
\hline 1. Didyctium sp. 1 & 10 & 8.5 & 22.22 & 22.22 \\
\hline 2. Apanteles sp. 1 & 1.75 & 8 & 21.13 & 43.35 \\
\hline 3. Meteorus sp. 1 & 0.5 & 2 & 5.644 & 48.99 \\
\hline 4. Polynema sp. 1 & 5 & 4 & 5.142 & 54.13 \\
\hline 5. Telenomus sp. 1 & 1.25 & 1 & 4.73 & 58.86 \\
\hline 6. Aganaspis sp. 1 & 0.25 & 1.5 & 4.46 & 63.32 \\
\hline 7. Anomalon sinuatum & 1 & 0 & 3.274 & 66.6 \\
\hline 8. Aphidius sp. 1 & 0.25 & 1 & 3.204 & 69.8 \\
\hline 9. Copidosoma sp. 1 & 0.25 & 1 & 2.805 & 72.6 \\
\hline
\end{tabular}

\section{Discussion}

It is known that the association with basil attracts lot of bees to the culture (Malerbo-Souza et al., 2000), which helps in the fruit production since sweet pepper is mainly pollinated by bees. In our experiment, it also acted as good attractive to parasitoids, as a higher quantity of parasitoids was found in the systems associated with basil (98 individuals) than in the monoculture (40 individuals). In the same way, the association with marigold provided an parasitoids increasing (130 individuals), as also found in plantations of onion (Silveira et al., 2009), garlic (Silva et al., 2012), lettuce (Haro, 2015), and kale (Silva et al. 2016). Numerous past studies support that vegetable diversification increases the number of parasitoid looking for food, host, and shelter (Pereira et al., 2015).

The most abundant insect in all associated treatments was the Didyctium sp. 1 (Hymenoptera: Figitidae), specially in associated treatment with basil. This genre is associated to the parasitism of Diptera Order insects, mainly those from the Phoridae family (Beardsley, 1989; Van Noort et al., 2015) and the Chloropidae family (Koçak and Özdemİr, 2012). The attractive plants are possibly attracting more their hosts than the monoculture.
The second most abundant taxa in the associated treatments was the Polynema sp. 1 (Hymenoptera: Mymaridae), which is an egg parasitoid that has a great range of host, but above all the Hemiptera (specially from the families Cicadellida, Membracidae, Miridae, Nabidae, and Anthocoridae) and the Odonata (Huber, 1986; Huber et al., 2009). The high abundance of this insect can be explained by the possible great abundance of Anthocoridae in the treatments because, as reported by Silveira et al., (2009), these insects are attracted by marigold.

Apanteles sp. 1 (Hymenoptera: Braconidae) was the third most abundant in the associated treatments, also more numerous in the association with marigold. These insects are parasitoids of the Lepidoptera larvae (Whitfield et al., 2001; Varone et al., 2015), an insect that is greatly found in any plantation. Also the Meteorus sp. 1 (Hymenoptera: Braconidae), which was found in great abundance, is a parasitoid of the Lepidoptera larvae (Berry et al., 2016; Sobczak et al., 2012).

Of great importance was also our finding of Aphidius genre individuals (Hymenoptera: Braconidae), including A. ervi and A. platensis that are important parasitoids of the aphids (Bueno et al., 1993), only in the associated treatments, showing us the good results as of these plants utilization as attractive plants. 
With the diversification, we found a significant difference in insect abundance along the treatments, with less insects in the monoculture than in the diversified treatments, a result also find by Root (1973), Andow (1991), Altieri and Rogé (2009), Nicholls and Altieri (2012). The Berber-Parker Index was also significantly different for monoculture, having less dominant insects. A noteworthy point is that parasitoids are highly related to their hosts and habitat (Shaw, 2006). The diversification provides a more complex habitat and, therefore, a more suitable habitat for parasitoids (Aranda and Graciolli, 2015; Fabian et al., 2013) that are at a higher and susceptible trophic level (Fabian et al., 2013), meaning they need a more stable habitat to live. The diversification provides better habitat quality than the monoculture, thus the parasitoids are more likely to live in these diversified habitats.

Looking at the Shannon diversity index and the insects richness we found no difference among treatments, indicating that the association with basil and marigold have no influence on these attributes in sweet pepper plantations when compared to monoculture. Using the Non-Metric Multidimensional Scaling (NMDS) for the insect abundance, which is a tool to find groups of similar patterns and create maps displaying the relative positions of a number of objects (Clarke, 1993; Kruskal and Wish, 1978), it was possible to find three groups of Didyctium sp., Apanteles sp., and Polynema sp., and both associated treatments were more closely related to it than the monoculture treatment, what meant that the monoculture was different from both associated treatments in parasitoids abundance. This was expected when diversifying the plantation, as proposed by Andow (1991) and Nicholls and Altieri (2012).

According to Clarke (1993), using ANOSIM (Analysis of Similarities) is possible to quantify this difference, and we found an Rglobal of 0.4283 , meaning that the difference was not great, but we also found a significant difference between monoculture and basil ( $p=0.0287)$, and between monoculture and marigold $(p=0.0301)$, reinforcing the results obtained by the NMDS graphic.

Overall, the difference of parasitoids composition in diversified sweet pepper plantations is related to the presence of marigold and basil, providing a difference in the parasitoids species when compared with monoculture, being Didyctium, Apanteles, and Polynema the responsible for such difference.

The SIMPER (Similarity Percentage) is an easy test for assessing which taxa are primarily responsible for an observed difference between groups of samples (Clarke, 1993). In our analyses, we found that the monoculture showed an average dissimilarity of $75.12 \%$ with the associated treatments to basil, and an average dissimilarity of $79.75 \%$ with marigold associated treatments. Moreover, when we compared both associated treatments we found only an average dissimilarity of $56.45 \%$, showing that these treatments are more similar among them than with monoculture.

In study made by Fabian et al. (2013), they figured out that vegetable diversifications with wildflower lines increase the diversity and abundance of pollinators and biological control agents, favoring a potentially stable Hymenoptera community. Similarly to the findings in our study, it showed the importance of diversified crop concerning monoculture. The marigold and basil treatments were better evaluated than sweet pepper monoculture in all indexes. The parasitoids attraction and diversity index was higher in marigold plants than in basil. In contrast, basil plants had higher richness in species than marigold. The vegetable diversification of marigold or basil may be recommended in sweet pepper crops because they attract natural enemies of the various sweet pepper pests. Although there was no significant difference, both associated treatments had a high similarity of parasitoids species, and the intercropping with marigold stood out when compared to basil.

As propose by Aranda and Graciolli (2015), it is important to know the Hymenoptera fauna in different environments. In the Brazilian sweet pepper crop, the parasitoids fauna is not well known, and the effects of the vegetable diversification are crucial factors for the structuring and composition of the parasitoids community because it can help to diminish the pesticides use in the crop due to the attraction of natural enemies of the pests. Therefore, the vegetable diversification with basil and marigold in sweet pepper crop positively affects the attraction of parasitoids.

\section{Conclusion}

Therefore, when cultivating sweet pepper in association with basil or marigold, we can have an increase in the parasitoids abundance. The association with basil and marigold brought no increment to the parasitoid diversity in organic sweet pepper, but we found 24 species of parasitoids associated to the sweet pepper, basil, and marigold intercropping.

This study sustains that the use of basil and marigold in the sweet pepper crop may have an influence on parasitoids attraction. Additional studies are needed to determine whether other vegetable species are more beneficial to increase the abundance of parasitoids within the sweet pepper crops, preferably those strongly orientated to practical issues such as the relative benefits of parasitoids.

\section{Acknowledgements}

We are grateful to Mr. Pedro and Mr. Jozimar of the Olericulture Sector of the Agriculture department at the Federal University of Lavras, in Lavras, MG. This work was supported by CAPES (Coordenação de Aperfeiçoamento de Pessoal de Nivel Superior).

\section{References}

AGÊNCIA NACIONAL DE VIGILÂNCIA SANITÁRIA ANVISA, 2013. Relatório de atividades 2012. Brasilia: Anvisa. 
ALTIERI, M.S. and ROGÉ, P. 2009. The ecological role and enhancement of biodiversity in agriculture. In: S. LOCKIE and D. CARPENTER, eds. Agriculture, biodiversity and markets: livelihoods and agroecology in comparative perspective. London; Earthscan, pp. 15-32.

ANAMIKA, P. K., MURALIDHARAN, P., PRAKASH, R., THENMOZHI, M., TEJA, S. and ASWINI, M., 2013. Evaluation of ethanolic extract of Ocimum tenuiflorum for antiepileptic activity. Indian Journal of Pharmacology, vol. 45, pp. 235.

ANDOW, D.A., 1991. Vegetacional diversity and arthropod population response. Annual Review of Entomology, vol. 36, no. 1, pp. 561-586. http://dx.doi.org/10.1146/annurev.en.36.010191.003021.

ARANDA, R. and GRACIOLLI, G., 2015. Spatial-temporal distribution of the Hymenoptera in the Brazilian Savanna and the effects of habitat heterogeneity on these patterns. Journal of Insect Conservation, vol. 19, no. 6, pp. 1173-1187. http://dx.doi. org/10.1007/s10841-015-9832-z.

AZADI, H., SCHOONBEEK, S., MAHMOUDI, H., DERUDDER, B., DE MAEYER, P. and WITLOX, F., 2011. Organic agriculture and sustainable food production system: main potentials. Agriculture, Ecosystems \& Environment, vol. 144, no. 1, pp. 92-94. http://dx.doi. org/10.1016/j.agee.2011.08.001

BASEDOW, T., HUA, L. and AGGARWAL, N., 2006. The infestation of Vicia faba L. (Fabaceae) by Aphis fabae (Scop.) (Homoptera: Aphididae) under the influence of Lamiaceae (Ocimum basilicum L. and Satureja hortensis L.). Journal of Pesticide Science, vol. 79, pp. 149-154

BEARDSLEY, J.W., 1989. Hawaiian Eucoilidae (Hymenoptera: Cynipoidea), key to genera and taxonomic notes on apparently non-endemic species. Proceedings of the Hawaiian Entomological Society, vol. 29, pp. 165-193.

BERRY, J.A., WALKER, G.P., BERRY, J.A., WALKER, G.P. and WALKER, G.P., 2016. Meteorus pulchricornis (Wesmael) (Hymenoptera: Braconidae: Euphorinae): An exotic polyphagous parasitoid in New Zealand. New Zealand Journal of Zoology, vol. 31, no. 1, pp.33-44. http://dx.doi.org/10.1080/03014223.2004.9518357.

BHUVANESHWARI, K., GOKULANATHAN, A., JAYANTHI, M., GOVINDASAMY, V., MILELLA, L., LEE, S., YANG, D.C. and GIRIJA, S., 2016. Can Ocimum basilicum L. and Ocimum tenuiflorum $\mathrm{L}$. in vitro culture be a potential source of secondary metabolites? Food Chemistry, vol. 194, pp. 55-60. http://dx.doi. org/10.1016/j.foodchem.2015.07.136. PMid:26471526.

BOWERS, W.S., NAULT, L., WEBB, R. and DUTKY, S., 1972. Aphid alarm pheromone: isolation, identification, synthesis. Science, vol. 177, no. 4054, pp. 1121-1122. http://dx.doi.org/10.1126/ science.177.4054.1121. PMid:17840606.

BUENO, B.H.P., GUTIERREZ, A.P. and RUGGLE, P., 1993. Parasitism by Aphidius ervi (Hym.: Aphidiidae): preference for pea aphid and blue alfalfa aphid (Hom.:Aphididae) and competition with A. smithi. Entomophaga, vol. 38, no. 2, pp. 273-284. http:// dx.doi.org/10.1007/BF02372563.

CAROVIĆ-STANKO, K., LIBER, Z., BESENDORFER, V., JAVORNIK, B., BOHANEC, B., KOLAK, I. and SATOVIC, Z., 2010. Genetic relations among basil taxa (Ocimum L.) based on molecular markers, nuclear DNA content, and chromosome number. Plant Systematics and Evolution, vol. 285, no. 1-2, pp. 13-22. http://dx.doi.org/10.1007/s00606-009-0251-z.

CLARKE, K.R., 1993. Non-parametric multivariate analyses of changes in community structure. Australian Journal of Ecology, vol.
18, no. 1, pp. 117-143. http://dx.doi.org/10.1111/j.1442-9993.1993. tb00438.x.

FABIAN, Y., SANDAU, N., BRUGGISSER, O.T., AEBI, A., KEHRLI, P., ROHR, R.P., NAISBIT, R.E. and BERSIER, L.F., 2013. The importance of landscape and spatial structure for hymenopteran-based food webs in an agro-ecosystem. Journal of Animal Ecology, vol. 82, no. 6, pp. 1203-1214. http://dx.doi. org/10.1111/1365-2656.12103. PMid:23863136.

FERNÁNDEZ, F. and SHARKEY, M.J., 2006. Introduccion a los Hymenoptera de la Región Neotropical. Sociedad Colombiana de Entomología y Universidad Nacional de Colombia, Bogotá, 894 p.

HAMMER, Ø., HARPER, D.A.T. and RYAN, P.D., 2001. PAST: Paleontological Statistics Software Package for Education and Data Analysis. Palaeontolia Electronica, vol. 4, no. 1, pp. 1-9. http:// dx.doi:10.1016/j.bcp.2008.05.025.

HARO, M.M., 2014. Recursos Florais de Tagetes erecta L. Mediando a composição de redes tróficas. Lavras: Universidade Federal de Lavras, 109 p. Phd Thesis

HARO, M.M., 2015 Chemical, spatial and temporal characteristics of T. erecta floral resources mediating agricultural food webs. Lancaster: Lancaster University. 154 p. Phd thesis.

HUBER, J.T., 1986. Systematics, biology, and hosts of the Mymaridae and Mymarommatidae (Insecta: Hymenoptera): 1758-1984. Entomography, vol. 4, pp. 185-243.

HUBER, J.T., VIGGIANI, G. and JESU, R., 2009. Order Hymenoptera, family Mymaridae. Arthropod Fauna of the UAE, vol. 2, pp. 270-297.

KAYA, I., YIGIT, N. and BENLI, M., 2008. Ocimum basilicum $\mathrm{L}$. and observation of the inhibition effect on bacterial cells by use of scanning electron microscopy. African Journal of Traditional, Complementary, and Alternative Medicines, vol. 5, no. 4, pp. 363369. http://dx.doi.org/10.4314/ajtcam.v5i4.31291. PMid:20161958.

KOÇAK, E. and ÖZDEMİR, M., 2012. Parasitic Hymenoptera reared from the insects on Heracleum platytaenium Boiss. (Apiaceae) with new faunistic. Turkish Journal of Zoology, vol. 36, no. 2, pp. 201-208. http://dx.doi.http://dx.doi.org/10.3906/zoo-1008-129.

KRUESS, A. and TSCHARNTKE, T., 1994. Habitat fragmentation, species loss, and biological control. Science, vol. 264, no. 5165, pp. 1581-1584. http://dx.doi.org/10.1126/science.264.5165.1581. PMid:17769603.

KRUSKAL, J.B. and WISH, M., 1978. Multidimensional Scaling. Beverly Hills: Sage Publications. http://dx.doi.org/10.4135/9781412985130.

MALERBO-SOUZA, D.T., MOTA, M.O.S., NOGUEIRACOUTO, R.H. and SOUZA, J.C., 2000. Insects associated with the inflorescences of basil (Ocimum basilicum L.). Revista Brasileira de Plantas Medicinais, vol. 2, no. 2, pp. 27-30.

MAROUELLI, W.A. and SILVA, W.L.C., 2012. Irrigação na cultura do pimentão. Brasília: Embrapa Hortaliças, 20 p. Embrapa Hortaliças-Circular Técnica, no. 101.

MARTINS, A.J., RIBEIRO, C.D.M., BELLINATO, D.F., PEIXOTO, A.A., VALLE, D. and LIMA, J.B.P., 2012. Effect of insecticide resistance on development, longevity and reproduction of field or laboratory selected Aedes aegypti populations. PLoS One, vol. 7, no. 3, pp. 1-9. http://dx.doi.org/10.1371/journal.pone.0031889. PMid:22431967.

MICHELE, B., 1996. Natural substances useful for the protection of the phytosanitaria of officinal plants: round table: cultivation 
and quality of officinal plants. Phytotherapy Research, vol. 10, pp. 180-183.

MITSUNAGA, T., MUKAWA, S., SHIMODA, T. and SUZUKI, Y., 2006. The influence of food supply on the parasitoid against Plutella xylostella L. (Lepidoptera: Yponomeutidae) on the longevity and fecundity of the pea leafminer, Chromatomyia horticola (Goureau) (Diptera: Agromyzidae). Applied Entomology and Zoology, vol. 41, no. 2, pp. 277-285. http://dx.doi.org/10.1303/aez.2006.277.

MITSUNAGA, T., SHIMODA, T. and YANO, E., 2004. Influence of food supply on longevity and parasitization ability of a larval endoparasitoid, Cotesia plutellae (Hymenoptera: Braconidae). Applied Entomology and Zoology, vol. 39, no. 4, pp. 691-697. http://dx.doi.org/10.1303/aez.2004.691.

MOERICKE, V.V., 1951. Eine Farbfalle zur Kontrolle des Fluges von Blattläusen, insbesondere der Pfirsichblattlaus, Myzodes persicae (Sulz.). Nachrichtenblatt des Dtsch. Pflanzenschutzdientes, vol. 3, pp. 23-24.

MONTSERRAT, C.B., JANSSEN, D., ACEDO, L.L., SALVADOR, E. and NAVARRO, M. M.T., 2012. Utilización de Mentha suaveolens Ehrh y Ocimum basilicum Linnaeus como plantas refugio para adelantar la instalación de Orius laevigatus Fieber (Hemiptera: Anthocoridae) en cultivo de pimiento. Boletin de Sanidad Vegetal, Plagas, vol. 38, pp. 311-319.

NICHOLLS, C.I. and ALTIERI, M.A., 2012. Plant biodiversity enhances bees and other insect pollinators in agroecosystems. A review. Agronomy for Sustainable Development, vol. 33, no. 2, pp. 257-274. http://dx.doi.org/10.1007/s13593-012-0092-y.

PANIZZI, A.R. and PARRA, J.P., 2009. Bioecologia e nutrição de insetos como base para o manejo integrado de pragas. Brasília: Embrapa Informação Tecnológica, Londrina: Embrapa Soja, pp. 1055-110.

PEREIRA, A.G., SILVA, R.B., DIAS, M.M. and PENTEADO-DIAS, A.M., 2015. Study on the Hymenoptera parasitoid associated with Lepidoptera larvae in reforestation and agrosilvopastoral systems at Fazenda Canchim (Embrapa Pecuária Sudeste) São Carlos, SP, Brazil. Brazilian Journal of Biology $=$ Revista Brasileira de Biologia, vol. 75, no. 4, pp. 783-789. http://dx.doi.org/10.1590/15196984.21913. PMid:26602340.

POVEDA, K., GÓMEZ, M.I. and MARTÍNEZ, E., 2008. Diversification practices: their effect on pest regulation and production. Revista Colombiana de Entomologia, vol. 34, pp. 131-144.

R DEVELOPMENT CORE TEAM, 2015. R: A language and environment for statistical computing. Vienna: R Foundation for Statistical Computing.

ROOT, R.B., 1973. Organization of a plant-arthropod association in simple and diverse habitats: the fauna of collards (Brassica Oleracea). Ecological Monographs, vol. 43, no. 1, pp. 95-124. http://dx.doi.org/10.2307/1942161.

ROXAS, A.C., 2009. Repellency of different plants against flea beetle Phyllotreta striolata (Chrysomelidae, Coleoptera) on pechay Brassica pekinensis. Philippine Entomologist, vol. 23, pp. 185.

SALINAS-SÁNCHEZ, D.O., ALDANA-LLANOS, L., VALDÉSESTRADA, M.E., GUTIÉRREZ-OCHOA, M., VALLADARESCISNEROS, G. and RODRÍGUEZ-FLORES, E., 2012. Insecticidal activity of Tagetes erecta extracts on Spodoptera frugiperda (Lepidoptera: Noctuidae). The Florida Entomologist, vol. 95, no. 2, pp. 428-432. http://dx.doi.org/10.1653/024.095.0225.

SERRATO, A., BARRERAS, J. and DÍAZ, F., 2007. Aceites esenciales del recurso genético Tagetes para el control de insectos, nematodos, ácaros y hongos. In: J.F. LÓPEZ-OLGUÍN, A. ARAGÓN-GARCÍA, C. RODRÍGUEZ-HERNÁNDEZ, M. VÁZQUEZ-GARCÍA. Sustancias Naturales Contra Plagas. Agricultura Sostenible. Texcoco: Colegio de Postgraduados, vol. 3, pp. 180-192.

SHAW, M.R., 2006. Habitat considerations for parasitic wasps (Hymenoptera). Journal of Insect Conservation, vol. 10, no. 2, pp. 117-127. http://dx.doi.org/10.1007/s10841-006-6288-1.

SILVA, A.W.B., HARO, M.M. and SILVEIRA, L.C.P., 2012. Diversity of the arthropod fauna in organically grown garlic intercropped with fodder radish. Revista Brasileira de Agroecologia, vol. 7, pp. 121-131.

SILVEIRA, L.C.P., BERTI FILHO, E., PIERRE, L.S.R., PERES, S.C. and LOUZADA, J.L., 2009. Marigold (Tagetes erecta L.) as an attractive crop to natural enemies in onion fields. Scientia Agrícola, vol. 66, no. 6, pp. 780-787. http://dx.doi.org/10.1590/ S0103-90162009000600009.

SOBCZAK, J.F., MAIA, D.P., MOURA, J.C.M.S., COSTA, V.A., and VASCONCELLOS-NETO, J., 2012. Natural history of interaction between Meteorus sp. Haliday, 1835 (Hymenoptera: Braconidae) and its hyperparasitoid Toxeumella albipes Girault, 1913 (Hymenoptera: Pteromalidae). Braz. J. Biol., vol. 72, no. 1, pp. 211-214.

SONG, B.Z., WU, H.Y., KONG, Y., ZHANG, J., DU, Y.L., HU, J.H. and YAO, Y.C., 2010. Effects of intercropping with aromatic plants on the diversity and structure of an arthropod community in a pear orchard. BioControl, vol. 55, no. 6, pp. 741-751. http:// dx.doi.org/10.1007/s10526-010-9301-2.

TILMAN, D., CASSMAN, K.G., MATSON, P.A., NAYLOR, R. and POLASKY, S., 2002. Agricultural sustainability and intensive production practices. Nature, vol. 418, no. 6898, pp. 671-677. http:// dx.doi.org/10.1038/nature01014. PMid:12167873.

SILVA, V.I.F.D., SILVEIRA, L.C.P.S., SANTOS, A., SANTOS, A.J.N.S. and TOMAZELLA, V. B., 2016. Companion plants associated with kale increase the abundance and species richness of the natural-enemies of Lipaphis erysimi (Kaltenbach) (Hemiptera: Aphididae). African Journal of Agricultural Research, vol. 11, no. 29, pp. 2630-2639. http://dx.doi.org/10.5897/AJAR2016.10941.

VAN NOORT, S., BUFFINGTON, M.L. and FORSHAGE, M., 2015. Afrotropical cynipoidea (Hymenoptera). ZooKeys, vol. 176, no. 493, pp. 1-176. http://dx.doi.org/10.3897/zookeys.493.6353. PMid:25878545.

VARONE, L., LOGARZO, G., MARTÍNEZ, J.J., NAVARRO, F., CARPENTER, J.E. and HIGHT, S.D., 2015. Field host range of Apanteles opuntiarum (Hymenoptera: Braconidae) in Argentina, a potential biocontrol agent of Cactoblastis cactorum (Lepidoptera: Pyralidae) in North America. The Florida Entomologist, vol. 98, no. 2, pp. 803-806. http://dx.doi.org/10.1653/024.098.0265.

WHITFIELD, J.B., CAMERON, S.A., RAMÍREZ, S.R., ROESCH, K., MESSINGER, S., TAYLOR, O.M. and COLE, D., 2001. Review of the Apanteles Species (Hymenoptera: Braconidae) attacking Lepidoptera in Bombus (Fervidobombus) (Hymenoptera: Apidae) colonies in the New World, with description of a new species from South America. Annals of the Entomological Society of America, vol. 94, no. 6, pp. 851-857. http://dx.doi.org/10.1603/00138746(2001)094[0851:ROTASH]2.0.CO;2. 